\title{
LIVELIHOOD ASSESSMENT OF AVOCADO GROWING IN WESTERN KENYA AND ITS
} SOCIOECONOMIC IMPLICATIONS USING AGRICULTURAL EXTENSION SERVICES

\author{
aOuma George*, bOdhiambo G. Duncan, cMusyimi David, dKwach Johnson \\ a Institute for Climate Change and Adaptation, University of Nairobi, Kenya. \\ ${ }^{b}$ Department Maseno university, School of agriculture and food security, Maseno,Kenya. \\ ${ }^{c}$ Maseno university, Department of Botany, Maseno,Kenya. \\ ${ }^{d}$ Kenya Agricultural and Livestock Research Organization, Kisii, Kenya.
}

\begin{abstract}
A B S T R A C T
Avocado (Persia americana) is an important world crop. In Kenya, it has become a very important crop, but its production is limited by several factors. Studies were conducted in the Lake Victoria Basin counties of Bunyala in Busia, Kisumu, Muhoroni, Nyando and Rachuonyo in western Kenya to investigate the socioeconomic factors affecting Avocado production. Information were collected from focus group discussions, key informants, individual interviews and secondary sources. Statistical Package for Social Scientist was used to analyze data collected interpreted and reported. The objectives were to assess how Avocado growers in western Kenya using Agricultural extension services affects the Livelihood of farmers considering their level of education and extension services and the implication it has on their decisions making to invest in Avocado production. There was positive relationship within the participating farmers as relates their level of education, income and availability of extension services that led to high adoption of inputs, choice of rootstocks to grow the crop, varieties chosen, planting, cultural practices harvesting, storage and marketing.
\end{abstract}

Keywords: Livelihood, avocado, production, extension services, Kenya.

\section{INTRODUCTION}

Avocado (Persea americana) belongs to the family Lauraceae. It is native to tropical America where it is divided into 3 sub-species or races i.e. Mexican (subtropical), Guatemalan (semi-tropical) and West Indian (tropical). Generally, Avocado is cultivated in tropical and sub-tropical regions from $400 \mathrm{~N}$ and $400 \mathrm{~S}$. It is unique among fruit trees in that it is neither sweet nor acidic but of bland nature with a remarkably high nutritional density. It contains $15-30 \%$ oil, similar in composition to olive oil, eleven vitamins (Vitamins A, B6, B12, K, C, E, Folacin, Niacin etc) and fourteen minerals. The calorific value is exceptionally high, 123-387 gmcal/100g edible avocado and has low sugar content (Bergh, 1991, Currier, 1991, Gaillard \& Gregory, 1995). Avocados are eaten fresh, salads with lemon juice, salt etc. Avocado is a complete food in terms of protein, containing nine essential amino acids although not in

* Corresponding Author:

Email: goumaoindo@yahoo.com

(C) 2018 ESci Journals Publishing. All rights reserved. proportion. It can almost substitute butter and meat and is called in many countries as poor man's butter. Avocado is one of the most nutritive fruits known (Currier, 1991; HCDA. 2004; Mickelbart et al., 2007)). Further it has several uses; as a natural cosmetic, with advantage in rapid skin penetration and as a superior natural sunscreen (Bose \& Mitra, 1996). Compared with almond, corn, olive and soybean oils, avocado oil has the highest skin penetration rate (Swisher, 1998).

According to Griesbach (2005) several varieties of Avocado were introduced in Kenya in the 1930s by the Portuguese. Commercial cultivation of avocado started in the 1960s (Griesbach, 2005). In Kenya, avocado cultivation is concentrated in the highlands between 1,200 and $1,800 \mathrm{~m}$. Avocado is grown in several agroecological zones mainly by small-scale farmers for subsistence, local markets and export (Cooper et al., 2003). About $70 \%$ of avocado in Kenya is grown in the former Central and Eastern Regions. Central Region produces $40 \%$, Eastern 28\%, Western 13\%, Rift Valley $10 \%$, Nyanza $6 \%$ and Coast $2 \%$ and Nairobi Region $1 \%$ 
(MoA, 2003). The main production areas are Muranga, Kiambu, and Thika Counties in Central Region, Embu and Meru in Eastern Region. Taita Hills in Coast Region and Kitale in Rift Valley Region. Although Kenya has 7,500 ha under avocado production yielding about 81,000 tons, about 30,000 to 40,000 tons is lost to poor pre- and postharvest handling practices; limited superior varieties or planting materials, poor tree crop management practices; poor infrastructure, poor market information, pests (thrips, scales, fruit fly and systates weevil) and diseases (root rot, anthracnose and Cercospora leaf spot) (MoA, 2005).

Avocado's world production of 3.2 million tons (FAO, 2004) makes it an important fruit crop internationally. North America and Central America are leading producers constituting about $80 \%$ of total production. Currently, Avocado represents about $17 \%$ of the total horticultural exports from Kenya. In 2003, total Avocado exports from Kenya was approximately $39 \%$ of total Avocado's annual production of 70,000 tons (Griesbach, 2005) while in 2011 the area under Avocado increased with 11246Ha with a production of 201, 478 tons (Yako et al., 2011). The objective of this study was to conduct a baseline survey on avocado production and utilization in five counties around the Lake Victoria Basin. The study assessed the livelihood implications, strategies and impact it has on smallholder farmers of avocado (Persia americana) production systems in Nyando, Muhoroni, Rachuonyo, Bunyala and Samia in Busia Counties and enumerates its implications for extension services in Western Kenya

Approach: In this study The Sustainable Livelihoods Approach (SLA) has been adopted (Figure 1) to help understand and analyze the livelihoods of the poor which is also used in planning new development activities and assessing the contribution to livelihood sustainability made by existing activities (DFID, 2000). Sustainable livelihoods approach offers a conceptual framework for understanding causes of poverty, analyzing relationships between relevant factors at micro, intermediate and macro-levels, and prioritizing interventions. The approach explicitly requires going beyond sectorial barriers, to look at more of the context in which people live (DFID, 1997; Ashley \& Diana1999; Ashley, 2000. DFID, 2000). There are variations on the SLA, emphasizing different aspects with many common elements. The SLA considers five assets or types of capital namely natural, human, financial, physical and social. It also integrates vulnerability contexts and livelihood strategies this was in line with survey of avocado production and marketing households in the relevant Counties of Western Kenya as analyzed and reported in this paper.

Livelihood Assets: Biratu (2008) indicated five assets or types of capital available to people namely natural, human, financial, physical and social. These five forms of capital have different characteristics. People, according to the livelihoods approach, rely for their success on the value of services flowing from the total capital stock. Different households with different access to livelihood assets are affected by the diversity of assets, quantity and balance between assets. Therefore, the study considers accessibility, quantity and balance of assets as benchmark information against which progress in the future can be measured from and the changes that might be brought about by the deployment of new innovations. Natural Capital: Natural capital refers to the biophysical elements such as water, air, soil, sunshine, woodlands and minerals. These are naturally occurring assets that are largely renewable. In this study, household land size and land under cultivation of Avocado were analyzed, reported and where possible the study has explored other livelihood contexts and outcomes (Nicholas et al., 2013).

Human Capital: Human capital is perhaps the most important livelihood support factor (Ndour, 2017). It is the people who are both the object and subject of development. Since this study was on smallholder farmers, their knowledge about agriculture, technology available, sources and levels of accessibility were investigated as carried out on farmers' exploring to agricultural extension.

Financial Capital: Financial capital is the medium of exchange and therefore central to the functioning of a market economy. Its availability is critical to the successful utilization of the other factors or assets. The small holders' farmers' in the study area were analyzes exploring to agricultural extension to while exposure them to financial services such as savings and access to cash credit (Bebbingtone, 1999; Nicholas et al., 2013; Mwihaki, 2015).

Physical Capital: Physical capital refers to man-made assets such as productive assets, housing quality and consumer durables. An analysis was done on the number and status of productive assets within the households (Bebbingtone, 1999; Ndour, 2017). 


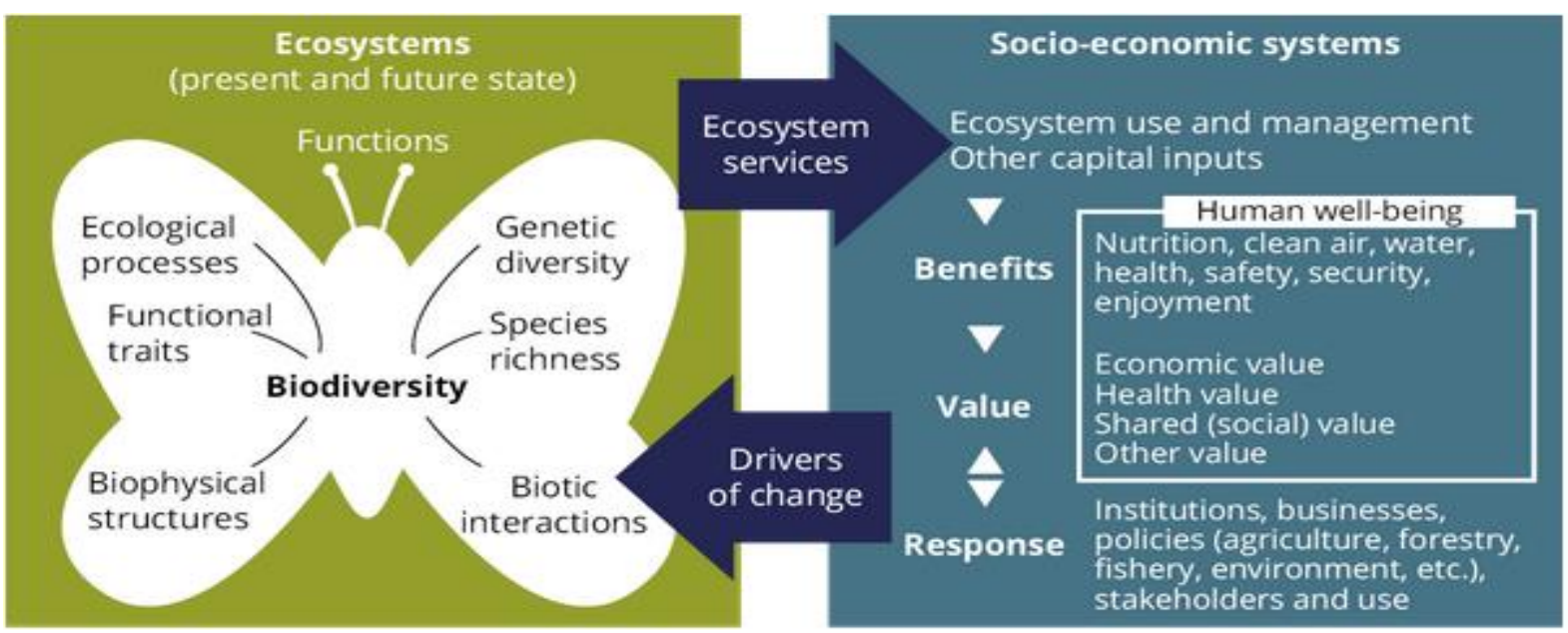

Source: Maes et al. (2003).

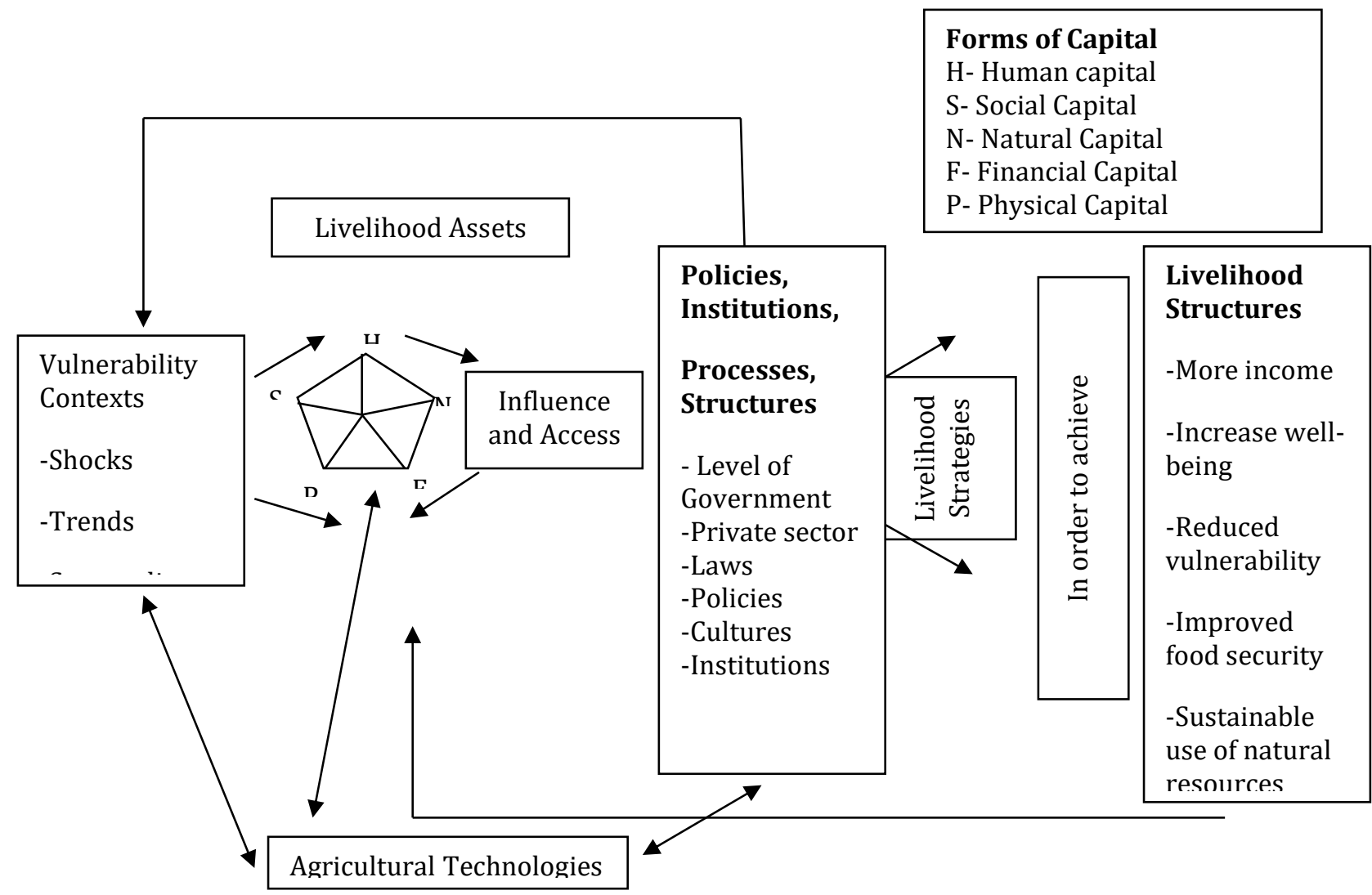

Figure 1. Sustainable Livelihood Framework.

Source: Adapted from DFID (2000).

Social Capital: Social capital according to Omotesho (2015) is the productive capital making possible the achievement of certain ends that would not be attained in its absence. Thus, social capital may be social resources upon which people draw, in seeking to achieve their livelihood outcomes, such as networks, and connectedness that increases their trust and ability to cooperate or membership to groups and their systems of rules, norms and sanctions (Manasib \& Jordan. 2015). These capital descriptive attributes were statistically analyzed within a typological group and mandate as reported. 
Vulnerability and Livelihood Strategies: People's livelihoods and availability of assets are fundamentally affected by critical trends (such as population, resource and technology, national and international economic) and shocks (such as human health, natural, economic, conflicts and crops/livestock heaths) and seasonality (of prices, of production, health and employment opportunities) (Moser, 1998; Nicholas et al., 2013). In general, people tend to have limited or no control on the vulnerability contexts. The factors (trends, shocks and seasonality) that make up the vulnerability contexts impact directly on people's asset status and the options open to them in pursuit of beneficial livelihood outcomes (Moser, 1998). Local households' vulnerability to climate change and livelihood strategies and outcomes were analyzed as reported.

\section{MATERIALS AND METHODS}

Study area: The survey was conducted in four Counties around the Lake Victoria Basin: Nyando with coverage of 1,168.4 Km2 predominantly black cotton clay soils with moderate fertility and poor drainage, rest has sandy clay loam soils derived from igneous rocks. Altitude lies from $1,100 \mathrm{~m}$ to $1,800 \mathrm{~m}$ asl of Nyabondo Plateau with bimodal annual precipitation of $600-1,630 \mathrm{~mm}$. The County is prone to flooding (Kano Plains) and water overflow that causes extensive erosion resulting in huge galleys (GoK, 1999). The second County was Muhoroni and Rachuonyo County with a population of 307,126 (1999 census) and an area of $945 \mathrm{Km}^{2}$ in Nyanza region of Kenya. The fourth County was Busia (Bunyala and Samia) in (Western Region). All the four Counties were selected based on their edaphic a climatic condition (i.e. salinity and water-logging), for food security and income generation. Bunyala has a total population of 58,773 lies to the north of Lake Victoria near the Kenya-Uganda border. Bunyala experiences bi-modal rainfall pattern per annum. The major season occurs in March to May (the long-rains season) while the other season (shortrains) occurs in October to December. The period JuneJuly is generally dry unlike other areas in western Kenya, which observe a major rainfall peak during the period. The months of January and February are also generally dry though occasional wet conditions may occur especially in January (GoK, 1999).

Sampling technique: Four counties were purposively sampled based on their edaphic and climatic (salinity and water-logging) conditions. Each County two divisions were selected while for Bunyala, four divisions for the study. Further, one administrative sub-location was selected from each division. Two villages were randomly sampled from each sub-location, from a list of all the villages in the selected sub-locations. The Listing of villages was done during reconnaissance survey by the research team and Frontline Extension Workers (FEWs) through the assistance of the area assistant chiefs. The FEWs were responsible for making lists of all the households within each village from which sample households were selected for the study.

Four steps were used to select the sample from targeted population. The first step involved developing a list of all villages in the selected sub-locations; second sampling four sample villages; third making a list of all households in the villages and lastly selection of the sample households from the village lists for survey. Thus, using the 'lottery technique', four villages were randomly sampled from each County. Using systematic sampling technique, 25 households were selected from each village for the survey. Thus, one household was selected randomly from among the first five households in each village through the 'lottery technique'. The next and subsequent households were then selected based on the interval established. An appropriate sampling interval (I) was calculated by dividing the total village household size $(\mathrm{N})$ by the required sample size (n) as follows:

$$
\mathrm{I}=\mathrm{N} / \mathrm{n}
$$

Where $\mathrm{I}=$ the interval; $\mathrm{N}=$ the total village household population and $\mathrm{n}=$ the sample size.

All households were assigned sequential numbers from $1 \ldots . . . \mathrm{n}$ for each County based on the village lists. If the first random household was, for example, 5, and the interval was 2 then the next $2^{\text {nd }}$ household on the list of households was selected along with every following 2 nd household until the required sample of 400 households was obtained.

Data Collected and analysis: Data was collected by means of a structured questionnaire and a checklist to individuals, Focus Group Discussion (FGD) and Key Informant Interviews (KII). The purpose of administering these tools were to assess their opinion on demographics, productive resources endowment, productivity costs, avocado production levels, vulnerability and capital assets and livelihoods. The data was then cleaned and analyzed using Statistical Package for Social Scientists (SPSS) for reporting. 


\section{RESULTS AND DISCUSSION}

\section{Socio-economic demographics}

Education: Exposure to education increases farmer's ability to access and use information relevant to adoption of improved technologies and hence, escalates yields and influence wealth (Jules et al., 2012; Usmann et al., 2013; Ndour, 2017). During the survey, respondents were requested to indicate the number of years of schooling completed. About $60.4 \%$ respondents, had completed primary level education; while Muhoroni County having the highest number, $72.5 \%$ and Nyando County having the lowest, $51.4 \%$, of the respondents respectively indicating that they had completed primary level education (Table 1). In the counties studied in the present study primary class seven appeared to be a sufficient formal education for successful farming.

Table 1. Gender, age and education demographics.

\begin{tabular}{|c|c|c|c|c|c|c|}
\hline \multirow{2}{*}{$\begin{array}{l}\text { Characteristi } \\
\text { c }\end{array}$} & \multicolumn{6}{|c|}{ Name of County } \\
\hline & $\begin{array}{c}\text { Muhoroni } \\
(\mathrm{N}=80)\end{array}$ & $\begin{array}{l}\text { Nyando } \\
(\mathrm{N}=80)\end{array}$ & $\begin{array}{c}\text { Rachuonyo } \\
(\mathrm{N}=80)\end{array}$ & $\begin{array}{c}\text { Bunyala East } \\
\qquad(\mathrm{N}=80)\end{array}$ & $\begin{array}{c}\text { Bunyala } \\
\text { West }(\mathrm{N}=80)\end{array}$ & All Counties $(\mathrm{N}=400)$ \\
\hline \multicolumn{7}{|c|}{ Gender } \\
\hline 1. Male & $72.5 \%$ & $71.2 \%$ & $71.2 \%$ & $66.2 \%$ & $58.8 \%$ & $68.0 \%$ \\
\hline 2. Female & $27.5 \%$ & $28.8 \%$ & $28.8 \%$ & $33.8 \%$ & $41.2 \%$ & $32.0 \%$ \\
\hline \multicolumn{7}{|c|}{ Age } \\
\hline 1. $<18$ Years & $1.2 \%$ & Nil & $3.8 \%$ & Nil & Nil & $1.2 \%$ \\
\hline $\begin{array}{ll}2 . & 19-30 \\
\text { Years } & \end{array}$ & $15.0 \%$ & $7.5 \%$ & $10.0 \%$ & $16.2 \%$ & $8.8 \%$ & $11.4 \%$ \\
\hline $\begin{array}{l}3 . \\
\text { Years }\end{array}$ & $23.8 \%$ & $16.2 \%$ & $30.0 \%$ & $25.0 \%$ & $21.2 \%$ & $23.1 \%$ \\
\hline $\begin{array}{ll}4 . & 41-50 \\
\text { Years } & \end{array}$ & $15.0 \%$ & $25.0 \%$ & $22.5 \%$ & $15.0 \%$ & $23.8 \%$ & $19.9 \%$ \\
\hline $\begin{array}{ll}5 . & 51-60 \\
\text { Years } & \end{array}$ & $20.0 \%$ & $20.0 \%$ & $13.8 \%$ & $21.2 \%$ & $10.0 \%$ & $17.1 \%$ \\
\hline 6. > 61Years & $25.0 \%$ & $31.2 \%$ & $20.0 \%$ & $22.5 \%$ & $36.2 \%$ & $27.3 \%$ \\
\hline \multicolumn{7}{|c|}{ Schooling } \\
\hline 1. None & $13.8 \%$ & $20.0 \%$ & $8.8 \%$ & $23.8 \%$ & $17.5 \%$ & $16.9 \%$ \\
\hline 2. Primary & $72.5 \%$ & $51.4 \%$ & $52.5 \%$ & $55.0 \%$ & $71.4 \%$ & $60.4 \%$ \\
\hline 3. Secondary & $12.4 \%$ & $23.7 \%$ & $33.7 \%$ & $21.2 \%$ & $9.9 \%$ & $20.0 \%$ \\
\hline 4. College & Nil & $3.8 \%$ & $5.0 \%$ & Nil & $1.2 \%$ & $0.5 \%$ \\
\hline 5. University & $1.2 \%$ & $1.2 \%$ & Nil & Nil & Nil & $0.4 \%$ \\
\hline
\end{tabular}

${ }^{*} \mathrm{~N}=$ Number of respondents

Households' access to financial services: Households' access to financial services is an indicator of a number of things. First that the households are able to get cash to improve their enterprises or start up new ones or that households are able to start up income generating activities to improve their livelihoods (Aker and Mbiti. 2010). In a rural set up, the farmers do not depend on banks but rely largely on Savings and Cooperative Societies (SACCOs) and Social Welfare Groups for financial assistance (Mwihaki, 2015). When asked whether they were members of any cooperative, majority of the respondents, $61.3 \%$, said no, with Bunyala West having the highest number, $86.2 \%$, saying no while Muhoroni had the lowest number, 32.5\%, saying no, respectively (Table 2). With Muhoroni having majority of the respondents indicating that they were members of cooperative societies indicates that the cooperative society movement has either been well 
established and taken root in the county or that the people have realized the importance of cooperatives and have started forming them. It would, therefore, be possible for farmers in Muhoroni to embrace the aspect of loans which would be very important in developing farming as a business compared to the other counties.

Table 2. Household membership to Cooperatives for credit facilities.

\begin{tabular}{lcccccc}
\hline Characteristic & \multicolumn{5}{c}{ Name of County } \\
\hline & $\begin{array}{c}\text { Muhoroni } \\
\left({ }^{*}=80\right)\end{array}$ & $\begin{array}{c}\text { Nyando } \\
(\mathrm{N}=80)\end{array}$ & $\begin{array}{c}\text { Rachuonyo } \\
(\mathrm{N}=80)\end{array}$ & $\begin{array}{c}\text { Bunyala East } \\
(\mathrm{N}=80)\end{array}$ & $\begin{array}{c}\text { Bunyala West } \\
(\mathrm{N}=80)\end{array}$ & All Counties (N=400) \\
\hline 1. Yes & & \multicolumn{2}{c}{ Member } \\
2. No & $65.0 \%$ & $35.0 \%$ & $48.8 \%$ & $15.0 \%$ & $11.2 \%$ & $35.0 \%$ \\
\hline
\end{tabular}

Extension services: This study specifically focused on human capital in relation to agricultural activities. In this section, human capital was analyzed from the perspective of agricultural extension, decision-making on key household enterprises and time allocation by key household members to the enterprises.

Extension is an important parameter of human capital and extensive ownership of mobile phones in the study areas is a boost to the flow of agricultural information from extension officers as discussed above under physical capital (Hopestone, 2014). Both government and private sector extension services help farmers to access new technologies and demonstrations on how to apply the various guidelines (Usmann et al., 2013; Akkad, 1990; Ndour, 2017). In addition, extension providers play an important role in monitoring and evaluation of these new technologies. Extension services play a major role in building the knowledge stock of farming communities (Jules et al., 2012). They help farmers to translate results into improvement in livelihoods. In Ethiopia extension has helped farmers replace their local crop landraces with improved varieties thus increasing crop yields and food security.(Biratu, 2008) while in Argentina it has resulted in increases in Grape yield, productivity and quality.(Pedro et al., 2008) In Kenya it has been similarly reported that it increases yields but this depends on factors such as availability of labour, farmers' level of education, types of crops grown, farmers' experience, farm management abilities of the farmer and agro-ecological characteristics of the farm. (Robert \& Mwabu. 1998). Visits by extension agents to farmers and participation of the latter in field days, seminars and/or agricultural shows are cost effective ways of reaching out with the new agricultural practice or technology to a large number of farmers (Abu \& Mahamudul. 2013; Haq et al., 2003). These workers reported that extension contact increases yields and incomes for farmers particularly for farmers near cities where the officers stay and where farmers have farm inputs and farmers are younger and educated with high incomes. In this study, farmers were asked whether they sought advice for crop and livestock production, source of extension advice and reasons for not seeking extension advice. Overall, $55.1 \%$ of the respondents indicated that they never sought extension advice. Bunyala East had $81.2 \%$ of the respondents indicating that they never sought extension advice. On the other hand, Nyando County had majority, $60 \%$, of the respondents indicating that they sought extension service. When they were asked to indicate the main source of extension service, they indicated the public sector. But a good number of respondents from Rachuonyo indicated the major source as being the private sector. Besides, the respondents were also asked to indicate why they never sought extension advice. They gave various reasons with some respondents indicating that the extension services were not available (Table 3).

Thus, any undertaking on fruit production and especially, avocado production should address the issue of extension. By the farmers indicating that they sought advice from the public sector indicates that they have confidence in the sector and probably any extension services should be channeled through the public sector. However, extension reforms are taking place in many countries to enable private agencies to be hired by farmers for this task (Rivera et al., 2000; Smith et al., 1997; Carner, 1998; Feder et al., 1999). 
Table 3. Sources and demand of extension services.

\begin{tabular}{|c|c|c|c|c|c|c|}
\hline \multirow[b]{2}{*}{ Characteristic } & \multicolumn{6}{|c|}{ County } \\
\hline & $\begin{array}{c}\text { Muhoroni } \\
\left({ }^{*} \mathrm{~N}=80\right)\end{array}$ & $\begin{array}{l}\text { Nyando } \\
(\mathrm{N}=80)\end{array}$ & $\begin{array}{l}\text { Rachuonyo } \\
(\mathrm{N}=80)\end{array}$ & $\begin{array}{l}\text { Bunyala East } \\
(\mathrm{N}=80)\end{array}$ & $\begin{array}{l}\text { Bunyala West } \\
(\mathrm{N}=80)\end{array}$ & $\begin{array}{l}\text { All Counties } \\
(\mathrm{N}=400)\end{array}$ \\
\hline \multicolumn{7}{|c|}{ Sought extension service } \\
\hline 1.Yes & $46.2 \%$ & $60.0 \%$ & $45.0 \%$ & $18.8 \%$ & $55.0 \%$ & $44.9 \%$ \\
\hline 2.No & $53.8 \%$ & $40.0 \%$ & $55.0 \%$ & $81.2 \%$ & $45.0 \%$ & $55.1 \%$ \\
\hline \multicolumn{7}{|c|}{ Source of extension } \\
\hline 1. Public extension agent & $15.0 \%$ & $15.0 \%$ & $12.5 \%$ & $6.2 \%$ & $45.0 \%$ & $18.4 \%$ \\
\hline 2. Private extension agent & $1.2 \%$ & $35.0 \%$ & $1.2 \%$ & $7.5 \%$ & $2.5 \%$ & $9.9 \%$ \\
\hline 3. Neighbor/farmer & $13.8 \%$ & Nil & $7.5 \%$ & $2.5 \%$ & $2.5 \%$ & $5.2 \%$ \\
\hline 4. ASK show & $2.5 \%$ & $3.8 \%$ & $1.2 \%$ & $1.2 \%$ & $1.2 \%$ & $2.0 \%$ \\
\hline 5. Input dealer & $1.2 \%$ & Nil & $11.2 \%$ & $1.2 \%$ & Nil & $3.0 \%$ \\
\hline 6. Radio/TV & Nil & $2.5 \%$ & $1.2 \%$ & Nil & Nil & $0.5 \%$ \\
\hline 7. Family/friend & $1.2 \%$ & $1.2 \%$ & Nil & $2.5 \%$ & $3.8 \%$ & $1.7 \%$ \\
\hline $\begin{array}{l}\text { 8. Farmer } \\
\text { organization/Cooperative }\end{array}$ & $2.5 \%$ & Nil & $2.5 \%$ & Nil & $2.5 \%$ & $1.5 \%$ \\
\hline 9. Field days/Demos & $1.2 \%$ & Nil & $1.2 \%$ & Nil & Nil & $0.5 \%$ \\
\hline 10. NGO agent & $10.0 \%$ & $1.2 \%$ & $6.2 \%$ & Nil & Nil & $3.5 \%$ \\
\hline 11. Research organization & Nil & Nil & Nil & $1.2 \%$ & Nil & $0.2 \%$ \\
\hline 12. Other & Nil & Nil & $1.2 \%$ & Nil & Nil & $0.2 \%$ \\
\hline \multicolumn{7}{|c|}{ Reasons for not seeking advice } \\
\hline 1. Long distance & $20.0 \%$ & $12.5 \%$ & $3.8 \%$ & $21.2 \%$ & $8.8 \%$ & $13.2 \%$ \\
\hline 2. Expensive & $8.8 \%$ & $8.8 \%$ & Nil & $5.0 \%$ & $15.0 \%$ & $7.4 \%$ \\
\hline 3. Time consuming & Nil & $1.2 \%$ & $1.2 \%$ & $3.8 \%$ & Nil & $1.2 \%$ \\
\hline $\begin{array}{l}\text { 4. Extension agent not } \\
\text { available }\end{array}$ & $17.5 \%$ & $10.0 \%$ & $18.8 \%$ & $12.5 \%$ & $15.0 \%$ & $14.9 \%$ \\
\hline $\begin{array}{l}\text { 5. Don't need extension } \\
\text { services }\end{array}$ & $5.0 \%$ & $10.0 \%$ & $20.0 \%$ & $35.0 \%$ & $1.2 \%$ & $14.1 \%$ \\
\hline 6. Other & $7.5 \%$ & Nil & $8.8 \%$ & $2.5 \%$ & Nil & $4.0 \%$ \\
\hline
\end{tabular}

${ }^{*} \mathrm{~N}=$ Number of respondents.

Payment for extension services: Provision of free extension services is becoming impracticable in the changing world (Nicholas et al., 2013). This then calls for cost-sharing in extension services i.e. the farmers have also to pay for extension services. This survey consequently sought to find out whether the respondents paid for extension services. The results indicated that $64.5 \%$ of the respondents were not paying for extension services with Rachuonyo leading with $80 \%$ followed by Muhoroni, 76\%. When they were asked whether they were willing to pay for extension service, $56.1 \%$ said no Bunyala East had $71.2 \%$ followed by Muhoroni at $65.0 \%$ of the respondents indicating that they would not be willing to pay for extension services. Willingness to pay for extension services appeared to have been affected by factors such as availability of skilled extension staff, farm productivity, size of farm, crop type; some crops such as fruits and vegetables are high value crops and can help the famer pay for extension services. (Onoh et al., 2012). 
Int. J. Agr. Ext. 06 (02) 2018. 71-79

Table 4. Payment for extension services.

\begin{tabular}{lcccccc}
\hline \multirow{2}{*}{ Characteristic } & $\begin{array}{c}\text { Muhoroni } \\
\left({ }^{*} \mathrm{~N}=80\right)\end{array}$ & $\begin{array}{c}\text { Nyando } \\
(\mathrm{N}=80)\end{array}$ & $\begin{array}{c}\text { Rachuonyo } \\
(\mathrm{N}=80)\end{array}$ & $\begin{array}{c}\text { Bunyala East } \\
(\mathrm{N}=80)\end{array}$ & $\begin{array}{c}\text { Bunyala West } \\
(\mathrm{N}=80)\end{array}$ & $\begin{array}{c}\text { All Counties } \\
(\mathrm{N}=400)\end{array}$ \\
\hline 1. Yes & $3.8 \%$ & $47.5 \%$ & $7.5 \%$ & $3.8 \%$ & $1.2 \%$ & $12.9 \%$ \\
2. No & $76.2 \%$ & $41.2 \%$ & $80.0 \%$ & $62.5 \%$ & $62.5 \%$ & $64.5 \%$ \\
\hline \multicolumn{7}{c}{ Paying for extension } \\
\hline 1. Yes & $30.0 \%$ & $66.2 \%$ & $46.2 \%$ & $28.8 \%$ & $33.8 \%$ & $41.2 \%$ \\
\hline No & $65.0 \%$ & $32.5 \%$ & $52.5 \%$ & $71.2 \%$ & $60.0 \%$ & $56.1 \%$ \\
\hline Cannot afford & $30.0 \%$ & Reasons for non-payment for extension service \\
\hline
\end{tabular}

$* \mathrm{~N}=$ Number of respondents.

Other factors which may have influenced these results are cost of extension services, economic benefits, access of government extension services, subsistence farming, quality of extension services (Udoka et al., 2016), farm size, farmer's level of education, can help the famer pay for extension services. (Ohno et al., 2012). Other factors which may have influenced these results are cost of extension services, economic benefits, access of government extension services, subsistence farming, quality of extension services (Udoka et al., 2016), farm size, farmer's level of education (Onoh et al., 2012). However, $66.2 \%$ of the respondents in Rachuonyo would be willing to pay for extension service. On the other hand, the farmers gave various reasons why they would not be willing to pay for the service. Topping the list infer that the farmers cannot afford to pay for extension service. Yet others felt that it is the responsibility of the government to provide extension services (Table 4). This scenario has several implications. One is that it would be difficult to sell extension services as a costsharing venture in Rachuonyo and Muhoroni counties. Any intervention aimed at scaling up extension services either on fruit production or any farming venture should aim at reversing this thinking that farmers cannot afford to pay for the services and/or that it is the responsibility of the government.

\section{REFERENCES}

Aker, J. C \& M. Mbiti. (2010). Mobile phones and economic development in Africa. Journal of Economic prospect, 24(3), 207-232.

Ashley, (2000). Applying livelihood approaches to natural resources management: experiences in Namibia and Kenya, ODI Working Paper 134, ODI. London
Ashley, C \& C. Diana. (1999). Sustainable livelihoods: Lessions from early experience DFID, 1999.

Bebbingtone, A. (1999) Capitals and Capabilities. A framework for analysing peasant viability, rural livelihoods and poverty reduction strategies. World Development. 26(1), 1-19.

Bergh, B.O. (1991). The avocado and human nutrition I. Some health aspects of the avocado proceedings. Proceedings of the World Avocado Congress II (WAC 91). Univesrity of California, California, pp $25-35$.

Biratu, G. K. (2008). Agricultural extension and its impact on food crop diversity and the livelihood of farmers in Guduru, Ethiopia. M.Sc Thesis, Norwegian University of Life Sciences.

Bose, T. K. \& S. K Mitra. (1996). Fruits: Tropical and Subtropical. Naya Prokash, Social Sciences, Agriculture and Horticulture, 206 Bidhan Sarani, Calcutta 700006, India.

Carner, D. (1998). Changing private and public roles in agricultural service provision, London, ODI, Natural Resources Group.

Cooper J., H. Dobson \& J. Orchard. (2003). Avocado production protocol- a document in consultation with avocado growers and exporters in Kenya. Natural Resources Institute. University of Greenwich, UK. 63 pp.

Currier, W. (1991). New variety introduction US condition. Proceedings of the World Avocado Congress II (WAC 91). University of California, California, pp $609-613$.

DFID (1997). Sustainable Livelihoods Guidance Sheets. DFID. London. UK.

DFID (2000). Sustainable Livelihoods Guidance Sheets. 
DFID. London. UK.

Feder, G., A. Willet, \& W. Zijp. (1999). Agricultural extension: Generic challenges and some ingredients for solutions. Washington DC World Bank Policy Working Paper 2129.

Food and Agricultural Organization (2004). Women and food security, FAO ROME.

Gaillard, J.P. \& J. Gregory. (1995). Avocado the tropical agriculture. Technical Centre for Africa (CTA). Macmillan Education Ltd, London, UK, 94- 110.

Government of Kenya (GoK). (1999) National Bureau of Statistics. Population Census. Kenya Bureau of Statistics Nairobi, Kenya.

Griesbach J. (2005). Avocado growing in Kenya. World Agroforestry Centre (ICRAF). Kul Graphics Ltd. Nairobi, Kenya

Haq A. Z., M.A Ishida, S. Yokoyama \& K. Taniguchi. (2003). Outcomes and issues of agricultural extension services in Bangladesh. Journal of Agricultural Extension Research, 8, 17.

Hopestone, K. C. (2014). The role of information communications technologies in agricultural production in Africa. Journal of Development and Agricultural Economics, 6(7), 279-289.

Horticultural Crops Development Authority (HCDA) Export Statistics. (2004). Kwambai T. (2006). Avocado production in the North Rift. Kenya Agricultural Research Institute -Kitale. Kenya.

Jules, M. N, F. Sikod. (2012). The Effects of human capital on agricultural productivity and farmer's income in Cameroon. International Business Research, 5, $4,20-25$.

Manasib A and K. Jordan. (2015) Effect of social capital on the choice to use sustainable agricultural practices. Journal of Agricultural and Applied Economics, 43(2), 213-227.

Mickelbart. M. V., S. Melser, \& M. L. Arpaia (2007). Salinity-induced changes in ion concentrations of 'Hass' avocado trees on three rootstocks. Journal of Plant Nutrition, 30,105-122.

Ministry of Agriculture (MoA). (2003). Horticulture Division Annual Reports. Ministry of Agriculture: Government of Kenya. Nairobi, Kenya.

Ministry of Agriculture (MoA) (2005). Horticulture Division Annual Reports. Ministry of Agriculture: Government of Kenya. Nairobi, Kenya.

Moser, C.O.N. (1998). The asset vulnerability framework: Reassessing urban poverty reduction strategies. World Development, 26(1),1-19.
Mwihaki, K.B. (2015). The relationship between agricultural financing and productivity of dairy farming in Central Kenya. MSc. Thesis University of Nairobi, Kenya.

Ndour C. T. (2017). Effects of human capital on agricultural productivity in Senegal. World Scientific News. 64: 34-38.

Nicholas Ozor, Chris Garforth \& Michael Madukwe. (2013). Farmer's willingness to pay for extension services in Nigeria, Journal of International Development, 25,282-392.

Omotesho, 0. A. (2015). Effect of social capital on productivity of rice in Kwara state, Nigeria, Science, Technology and Arts Journal, 4,1.

Onoh, P. A., C.C. Asiabaka, M. C.C. Edna \& E. P. Onoh (2012). Determinants of farmers' willingness to pay for agricultural extension services in S.E Nigeria, 43(1), 1-10.

Pedro Cerd'an-Infantes, A. Maffioli \& D. Ubfali. (2008). impact of agricultural extension services: The case of grape production in Argentina. Inter-American Development Bank, Office of Evaluation and Oversight Working Paper: /WP-05/08 June 2008.

Rivera, W. M., Z. Willem, A. Gory, A. Vin, L. Crowder, J. V. Andersen. (2000). Contracting for extension: Review of emerging practices agricultural knowledge and information systems. Good practice Note, Washington DC, World Bank.

Robert E. E. \& G. Mwabu. (1998). Effects of agricultural extension on farm yields in Kenya. Economic growth centre, Yale University, Centre Discussion Paper No.798.

Smith, L. D. (1997). Decentralization and rural development, Rome, FAO, SARD.

Swisher, H. E. (1998). Avocado Oil: From food use to skin care. Journal of Oil Chemicals Society, 65, 1704-1706.

Udoka, D. O., D. O. Mbati \& S. B. Duke. (2016). Effect of commercial bank's credit on agricultural production in Nigeria. Journal of Finance and Accounting, 4(1), 1-10.

Usmann, A. B., T. D Haratu \& A. M. Abubaker. (2013). Socio economic factors affecting groundnut production in Kaduna State, Nigeria.

Yako, W., g. Mbuthi, J.Simiyu, P. Oncheke, J. Kioko, J. Mauondu, D. Kamande, M. Githinji, Tunya, V. Wasike, Miriam. (2011). Horticultural validated report. Horticultural Crops Development Authority, Ministry of Agriculture Kenya. USAID, Horticultural Competitive Project Kenya. 